\title{
Is There an Implied Constitutional Right of Freedom of Communication?
}

\author{
Gabriël A. Moens and John Trone
}

I

n its 1992 decision Australian Capital Television v Commonwealth, ${ }^{1}$ the High Court of Australia invalidated the Commonwealth government's prohibition on electoral advertising on the ground that it infringed an implied constitutional right of freedom of communication with respect to the government of the Commonwealth. In a companion case, Nationwide News $\mathbf{v}$ Wills, ${ }^{2}$ Brennan, Deane, Toohey and Gaudron JJ also invalidated a Commonwealth law that prohibited the publication of material calculated to bring the Industrial Relations Commission into disrepute, on the basis that it infringed such an implied freedom.

Yet although the Court's decisions correctly identify the inhibiting effect of the impugned legislative provisions on freedom of speech, in our opinion they could not be based on the existence in the Constitution of implied limitations on federal power. On the other hand, the High Court could have held that the relevant legislative provision violated a different implication that is at least supported by current authority.

\section{Implied Limitations on Federal Power}

In the leading Engineers case, ${ }^{3}$ the High Court condemned judicial censorship of extravagant use of Commonwealth power. The High Court pointed out that 'possible abuse of powers is no reason in British law for limiting the natural force of the language creating them'. ${ }^{4}$ The extravagant use of federal power presented a political issue, which required a political response: as long as it was within power, it could not be invalidated by the Court. Four members of the Court said in a joint judgment:

1 (1992) 177 CLR 106, 108 ALR 577 (Mason CJ, Deane, Toohey and Gaudron JJ).

2 (1992) 177 CLR 1, 108 ALR 681.

${ }^{3}$ Amalgamated Society of Engineers v Adelaide Steamship Co. Ltd(1920) 28 CLR 129.

4 Id. 151.

Gabriël Moens is an Associate Professor, and John Trone a research assistant, in the School of Law at the University of Queensland. 
[T] he extravagant use of the granted powers in the actual working of the Constitution is a matter to be guarded against by the constituencies and not by the courts. . If . . . the representatives of the people of Australia as a whole ... proceed to use their national powers to injure the people of Australia considered sectionally, it is certainly within the powers of the people themselves to resent and reverse what may be done. No protection of this court in such a case is necessary and proper. ${ }^{5}$

They identified the correct method of constitutional interpretation as 'in the actual terms of the instrument their expressed or necessarily implied meaning', thus admitting that there was a role for implication in constitutional interpretation. The role of the technique of implication was never disowned by the High Court. But this role was a limited one, and the only implications that could be made were those that must be 'necessarily implied' from 'the actual terms of the instrument'. ${ }^{6}$ The Court was not free to limit the language of a federal power or to invent implied prohibitions upon the exercise of federal power.

This method of interpretation was accepted by later courts. In Adelaide Company of Jehovah's Witnesses v Commonwealth, 'Latham $\mathrm{CJ}$ stated that 'In the absence of a relevant constitutional prohibition it is not a proper function of a court to limit the method of exercising a legislative power'. ${ }^{8}$ The Court took the view that, except for express constitutional prohibitions, the legislative power of the Commonwealth and State parliaments was as plenary as that of the British Parliament. The Court's role was limited to deciding whether the State or federal legislature had power to enact the law. The Court invalidated federal laws only if they could not be supported by one of the heads of power in 5.51 of the Commonwealth Constitution. In implying a right of freedom of communication in relation to the government of the Commonwealth, the High Court has, as an intellectual matter, effectively discarded the interpretative technique that it has used since 1920 .

\section{Representative Democracy and Freedom of Communication}

In its 1992 decisions, the High Court generated controversy because, contrary to accepted canons of construction, it had suddenly discovered a new entrenched, but implied, right to freedom of communication. The High Court drew an implication of freedom of communication relating to Commonwealth governmental affairs from the system of representative government that the Constitution creates.

\footnotetext{
${ }^{5}$ Id. n.4 at $151-2$ (Knox CJ, Isaacs, Rich and Starke J).

${ }^{6}$ Id. 155.

7 (1943) 67 CLR 116.

${ }^{8}$ Id. 133 (Latham CJ).
} 
The Constitution certainly provides for a system of representative democracy, which involves the idea of government by the people through their elected representatives. ${ }^{9}$ This system is based mainly on s.7 (senators directly chosen by the people of the State) and s.24 (constitution of House of Representatives). But the Court's invocation of these sections goes no further than to show that the Constitution provides for a system of representative government in the terms of those sections. The constitutional blueprint for representative government was deliberately limited. As Dawson J pointed out, 'much is left to the Parliament concerning the details of the electoral system to be employed in achieving representative democracy'. ${ }^{10}$

Despite express provision for a right to vote, the Court ruled as recently as 1975 that 'representative democracy' does not demand equality of population in federal electorates. The suffrage is surely the core of representative democracy, both constitutionally and practically. But the Court would not imply restrictions upon the federal parliament's power to interfere with the weightage of votes. ${ }^{11}$ Yet now the Court has taken the view that representative government cannot effectively exist without an implied right of freedom of political communication.

To bolster its conclusion, the High Court embarks upon a lecture on civics, describing a number of characteristics of desirable or good government. It makes a number of unobjectionable factual statements, perhaps hoping that those who criticise the decision will be reduced to questioning the truth of these statements. It draws together a miscellany of obiter dicta from earlier decisions from around the world about the practical importance of free speech to good government. Some of these cases are from jurisdictions with express guarantees of freedom of speech.

But the Australian Capital Television and Nationwide decisions are conspicuously devoid of reasons why these attractive factual considerations elevate freedom of expression to a right enshrined in the Commonwealth Constitution. This is their real weakness, and the Court made little headway in overcoming it. Much of the discussion about representative government bears greater resemblance to an amateurish exercise in political science than it does to a legal interpretation of the constitutional text. Take for instance the Chief Justice's lecture on the necessity of free speech to ensure the accountability of members of parliament in a system of representative government:

Indispensable to that accountability and that responsibility is freedom of communication, at least in relation to public affairs and political discussion. . . Absent such a freedom of communication, representative government would fail to achieve its purpose, namely, government by the people

\footnotetext{
${ }^{9}$ See ss.1, 7, 24, 25, 61, 62, 64 discussed in Australian Capital Television, CLR at 137, ALR at 593 (Mason CJ). See also id. CLR at 210-1, ALR at 650-1 (Gaudron J).

10 Australian Capital Television, CLR at 185, ALR at 630.

11 Attomey General (Cth); ex rel. McKinlayv Commonwealth (1975) 135 CLR 1.
} 
through their elected representatives; government would cease to be responsive to the needs and wishes of the people and, in that sense, would cease to be truly representative. ${ }^{12}$

Mason CJ is concerned here that representative government must achieve its purpose, yet the Constitution, in providing for representative government, does not stipulate that the best or most desirable form of representative government - if such a form can be identified - be realised. The Chief Justice is also concerned that government be truly 'responsive to the needs of the people'. These are fine matters for a citizen to be concerned with.

Deane and Toohey J's judgment reveals a similar intrusion of nonconstitutional considerations:

The people of the Commonwealth would be unable responsibly to discharge and exercise the powers of governmental control which the Constitution reserves to them if each person was an island, unable to communicate with any other person. The actual discharge of the very function of voting in an election or referendum involves communication. An ability to vote intelligently can exist only if the identity of the candidates for election or the content of a proposed law submitted for the decision of the people at a referendum can be communicated to the voter. ${ }^{13}$

Deane and Toohey $\mathrm{J}$ reveal a concern that the people 'responsibly' exercise their right to vote. They implicitly deplore the notion that each person could be made an island, and are concemed that each person should exercise the franchise 'intelligently'. But although we share each of these concerns, we do not see how such concerns constitutionalise a right to free speech.

The majority's reasons were essentially derived from their own beliefs rather than the text of the Constitution. ${ }^{14} \mathrm{We}$ are curious as to why the people are presumed to have not intended to give the Parliament plenary power, when with a few specific exceptions the very words of the Constitution they created provides no contrary indication and the parliamentary model they knew best was possessed of unlimited powers and when they rejected the example of the United States about how to limit these powers. The Australian people divided governmental power, but did not limit it.

The process of implication itself is fraught with difficulty. How are the judges to identify just what fundamental rights will be protected? Such a process is inherently

12 Australian Capital Television, CLR at 138-9, ALR at 594 (Mason CJ).

13 Nationwide, CLR at 72, ALR at 723 (Deane and Toohey J).

${ }^{14}$ See too Australian Capital Television, CLR at 230-1, ALR at 666-7 (McHugh J), Nationwide, CLR at 47-8, ALR at 704 (Brennan J). 
dependent on the individual judge's social and moral beliefs. These are natural difficulties where a court implies prohibitions not discernible in the text itself. Even Mason CJ admitted the existence of these difficulties in Australian Capital Televisiorr.

[I]t is difficult, if not impossible, to establish a foundation for the implication of general guarantees of fundamental rights and freedoms. To make such an implication would run counter to the prevailing sentiment of the framers that there was no need to incorporate a comprehensive Bill of Rights in order to protect the rights and freedoms of citizens. That sentiment was one of the unexpressed assumptions on which the Constitution was drafted. ${ }^{15}$

Nevertheless, the process of implying rights in the Constitution is accelerating. In a dissenting judgment in 1991, Deane and Toohey IJ implied a constitutional guarantee of equal legal treatment: the underlying equality of the people of the Commonwealth under the law and before the courts. ${ }^{16}$ They would have invalidated a Commonwealth sentencing law that left the duration of the sentence to be determined by State law, so that the minimum sentence varied from State to State. The majority view of Mason CJ, Dawson, and McHugh JJ in that case is preferable. They correctly held that no implication was able to be made that the Constitution demanded that federal laws operate uniformly throughout the Commonwealth and that they not be discriminatory.

The right to freedom of political communication is more an unexpressed assumption than an implication necessarily made. An 'unexpressed assumption' differs from 'an implication necessarily made' in that the former is an extraconstitutional notion, whereas the latter is part of the constitutional document. As Dawson J stated, 'If implications are to be drawn, they must appear from the terms of the instrument itself and not from extrinsic circumstances'. ${ }^{17}$ He went on to say that 'The nature of the society or, more precisely and accurately, the nature of the federation which the Constitution established, is to be found within its four corners and not elsewhere'. ${ }^{18}$

\footnotetext{
15 CLR at 136, ALR at 592 (Mason CJ). But note that Mason CJ describes it as an unexpressed assumption rather than as something which inheres in the document, such as responsible government. He has signalled his preparedness to give less credence to the former than the latter: CLR at 135, ALR at 591 .

${ }^{16}$ Leeth v Commonwealth (1992) 174 CLR 455, 484-7. They had previously hinted at such an implication: see Queensland Electricity Commission v Commonwealth (1985) 159 CLR 192, 247-8 (Deane J; Streetv Queensland Bar Association (1989) 168 CLR 461, 554 (Toohey J).
}

${ }^{17}$ Id. CLR at 181, ALR at 627.

18 Australian Capital Television, CLR at 186, ALR at 631-2. 
One of the most ironic aspects of the Court's judgment in the political advertising case is that it has essentially adopted the approach to constitutional interpretation of Murphy J, despite having decisively rejected it while he was on the Bench In support of an implied freedom of speech, Murphy $J$ actually appealed to the institution of representative government. In Millerv TCN Channel Nine ${ }^{19}$ he said:

The Constitution . . . contains implied guarantees of freedom of speech and other communications and freedom of movement not only between the States and the States and the Territories but in and between every part of the Commonwealth. Such freedoms are fundamental to a democratic society. They are necessary for the proper operation of the system of representative government at the federal level. ${ }^{20}$

Several members who are now part of the majority in Australian Capital Television conspicuously rejected Murphy J's theory of an implied guarantee of freedom of communication. ${ }^{21}$ Some acknowledgment of the Court's sources for its new doctrine is due. ${ }^{22}$

\section{The Legitimacy of the Advertising Ban}

The prohibition on political advertising was assuredly a severe invasion of free speech. But we disagree with the opinion of Brennan $J$ that the ban could be considered a legitimate restriction upon free speech. He said: 'It was open to the Parliament to conclude, as the experience of the majority of liberal democracies has demonstrated, that representative government can survive and flourish without paid political advertising on the electronic media during election periods. ${ }^{23} \mathrm{He}$ fully accepted the government's claim that the legislation was passed with the object of 'minimizing the risk of corruption or of reducing the untoward advantage of wealth on the formation of political opinion'.24

Yet in reality the ban struck at the heart of democratic values: it prohibited political communication, the core of free speech in a liberal democratic society. The ban was imposed at the most important time in the political process: the period

\footnotetext{
19 (1986) 161 CLR 556.

${ }^{20}$ Id. 581-2.

${ }^{21}$ See also rejection of Murphy J's views at 569 (Gibbs CJ), 637 (Dawson J).

22 But see Australian Capital Television, CLR at 212, ALR at 652 (Gaudron J).

${ }^{23}$ Australian Capital Television, CLR at 161, ALR at 612 (Brennan J).

${ }^{24}$ Id. CLR at 156, ALR at 608 (Brennan J).
} 
preceding elections. This is when voters most need information about candidates and parties, and when people most wish to speak. The legislation imposed a discriminatory regime effectively allowing only those already represented in parliament to speak through one of the most important mediums of communication. Brennan $\mathrm{J}$ at no stage offered convincing evidence of the link between political advertising on television or radio and corruption or undue influence in the political process. The government might be entitled (within limits) to address such a problem; but it did not establish even the existence of a problem. McHugh J's comment on this issue is apposite:

If the Australian political process can be corrupted by the cost of political advertising, those bent on corrupting that process will not lack opportunities to achieve their ends even if electronic political advertising is prohibited during an election period. As the Supreme Court of the United States pointed out ... 'virtually every means of communicating ideas in today's mass society requires the expenditure of money. ${ }^{25}$

It was argued that television advertising debases or trivialises political debate. Even if this is true, it does not constitute a sufficient reason for banning it from political debate. The best way of ensuring that false ideas are exposed as false is to allow them to be aired openly. As United States Supreme Court judge Oliver Wendell Holmes observed long ago: 'the ultimate good desired is better reached by free trade in ideas ... for the best test of truth is the power of thought to get itself accepted in the competition of the market'. ${ }^{26}$ If the people do not like the messages given in a political party's advertising they may exercise their choice accordingly at the ballot box.

Brennan J also invoked the spectre of the destruction of representative democracy if the ban were not upheld. He said: 'if performance of the duties of members of the Parliament were to be subverted by obligations to large benefactors or if the parties to which they belong were to trade their commitment to published policies in exchange for funds to conduct expensive campaigns, no curial decree could, and no executive action would, restore representative democracy to the Australian people. ${ }^{27}$

This statement invites two comments. First, when he argues in support of the compatibility of the ban with liberal democracy, Brennan J neglects the converse of what he says about the destruction of representative democracy. This is that the United States and other nations allowing freedom of speech in these matters have not ceased to be representative democracies or succumbed to dictatorship. The

25 Australian Capital Television, CLR at 239, ALR at 673 (McHugh J).

26 Abrams v United States (1919) 250 U.S. 616, 630.

27 Id. CLR at 156, ALR at 608 (Breman J). 
onus must be upon those seeking to defend a prohibition upon speech to justify its necessity. The evidence that televised political advertisements were somehow undermining Australian democracy is insufficient.

Second, it is very difficult indeed to see how this statement by Brennan $\mathrm{J}$ in any way justifies a ban on electoral advertising. Accepting for the sake of argument the likelihood of corruption attributable to the need for campaign donations, the target in such a case ought surely to be political donations rather than a medium of communication. Even if it is accepted that the great expense of broadcast advertising is particularly likely to create a sense of obligation on the part of political parties, it is the financial factor that is the problem rather than the speech itself.

Like Brennan J, Mason CJ was also prepared to assume for the purpose of deciding the case that all of the Commonwealth's contentions were true. He assumed that the need to raise considerable amounts of money to conduct election campaigns could create a risk of corruption and undue influence; that the wealthy have an advantage in utilising this medium of communication; and that short election commercials may 'trivialise' political debate. ${ }^{28}$ Yet he found that the ban was still unjustifiable.

\section{An Alternative to an Implied Right}

For the reasons mentioned above, we strongly espouse the Court's opinion that the federal government's ban upon political advertising was a violation of free speech. We do not, however, support the manner in which it reached its conclusion that the relevant legislative provisions were invalid. Yet if the High Court had wished to decide the political advertising case on a narrower ground, it could have held that the relevant legislative provision violated a different implication that is at least supported by current authority. This implication is the prohibition that was applied in the Melbourne Corporation case. ${ }^{29}$

The Melboume Corporation prohibition involves two tests. The first is a discrimination test: legislation must not discriminate against or between the States. The advertising prohibition certainly passed this test. The prohibition upon State political advertising was part of a general legal regime; it did not single out the States or a State. The second test is a preservation test: legislation must not destroy or impair the capacity of the States to function. The legislation failed this test because it prohibited political advertising in relation to State electoral processes. Indeed, it prevented the States from reaching the electorate through electronic advertising even during a referendum campaign that might confer increased legislative power upon the Commonwealth. ${ }^{30}$

${ }^{28}$ Id. CLR at 144-5, ALR at 599 (Mason CD).

${ }^{29}$ Melbourne Corporation v Commonwealth (1947) 74 CLR 31.

${ }^{30}$ Donald Speagle, case note (1992) 18 Melboume University Law Review 938, 946. 
The High Court could therefore have concluded that the legislation unconstitutionally inhibited the workings of the States, and could have partially invalidated the legislation on this ground.

McHugh $\mathrm{J}^{31}$ and Brennan $\mathrm{J}^{32}$ correctly applied the preservation test to invalidate the legislation as applied to State electoral processes. As McHugh J stated, its 'immediate object [was] to control the States and their people in the exercise of their constitutional functions'. ${ }^{33}$ McHugh J argued that the continuance of the States as independent legal entities with their own constitutions and parliaments required that Commonwealth legislative power did not extend to interference in the electoral processes of the States, subject to a clear contrary intention in the Constitution. ${ }^{34}$

Furthermore, rather than containing an implied right of political communication, the Constitution contains in $\mathbf{5 . 9 2}$ an express freedom of interstate trade, commerce and intercourse that, but for the Court's recent negation of much of the effect of that guarantee, would have crippled the Commonwealth's prohibition of political advertising. In Barley Marketing Board (NSW) v Norman, ${ }^{35}$ the High Court decisively rejected the individual rights theory of s.92, according to which the Constitution is breached if governmental regulation impedes a person's right to interstate communication. Because of national networking most television and radio broadcasting could be considered interstate broadcasting. If the High Court had not restrictively interpreted s.92, the political advertising ban could easily have been invalidated for violation of an express constitutional prohibition. It is ironic that as a consequence of the Court's earlier restrictive interpretation of an express right enshrined in $s .92,{ }^{36}$ the Court was later compelled to invent an implied right to freedom of political communication.

31 Australian Capital Television, CLR at 241-44, AIR at 675-7.

32 Id. CLR at 162-64, ALR at 613-4.

${ }^{33}$ Id. CLR at 241, ALR at 675.

${ }^{34}$ Id. CLR at 242-3, ALR at 675-6.

35 (1990) 171 CLR 182, 201.

${ }^{36}$ See in particular Colev Whitfield (1988) 165 CLR 360. 